NBER WORKING PAPER SERIES

\title{
MONETARY POLICY LESSONS OF RECENT \\ INFLATION AND DISINFLATION
}

William Poole

Working Paper No. 2300

NATIONAL BUREAU OF ECONOMIC RESEARCH 1050 Massachusetts Avenue

Cambridge, MA 02138

June 1987

The research reported here is part of the NBER's research program in Economic luctuations. Any opinions expressed are those of the author and not those of the National Bureau of Economic Research. 
NBER Working Paper \#2300

June 1987

Monetary Policy Lessons of Recent Inflation and Disinflation

$\underline{\text { ABSTRACT }}$

The decline of velocity in the 1980s is a surprise that should not have been. Economists unwisely relied on a velocity trend of 3 percent per year when they should have insisted on an economic explanation for rising velocity. An analysis of velocity and interest rates from 1915 to 1986 suggests that the interest elasticity of money demand is substantially higher than previously thought. The postwar increase of rates followed by a major decline of rates in the 1980 s explains velocity behavior. The large decline in velocity almost certainly would have caused severe economic problems had the Federal Reserve not accommodated the decline through more rapid money growth.

Federal Reserve policy between October 1979 and october 1982 emphasized control of money growth. Money market behavior during this period, compared to periods before and after, provides strong evidence that the market sets interest rates on the basis of a sophisticated understanding of monetary policy. The evidence makes clear that the monetary authorities cannot use interest rates to provide information on the state of the economy unless they know the extent to which interest rates reflect expectations of future monetary policy.

William Poole Department of Economics Brown University

Providence, RI 02912 


\section{MONETARY POLICY LESSONS OF RECENT INFLATION AND DISINFLATION}

\section{William Poole*}

By 1975 most economists agreed that the money demand function in the United States was reasonably stable and could serve reliably as the basis for monetary policy formulation. Those suspicious of monetarism were on the defensive in light of the apparently inexorable increase of M1 velocity of about three percent per year with deviations of only a few tenths of a percent. Experience with rising money growth and rising inflation through 1980 only confirmed monetarist views.

As Figure 1 shows, by 1986 all this had changed. With disinflation in the 1980s M1 velocity departed convincingly from its 1953-79 trend. The money demand function seems to have fallen apart, and is apparently not a reliable basis for monetary policy after all. Consequently, the first major section following this introduction is devoted to the decline of velocity after 1981 and the demise of the "standard" money demand function. The second section contains some thoughts on repairing the standard function.

Events have not been kind to Keynesian monetary policy positions either. Keynesians tend to concentrate on interest rates -- especially real interest rates -- as the best guide to the effects of monetary policy on the economy. The real rate is discussed in the third section of the paper. As can be seen in Figure 2, real rates rose sharply in late 1979 and remained high through 1985.1 The severity of the 1981-82 recession (as measured, say, by the peak unemployment rate of almost 11 percent) is consistent qualitatively with the high real rate of interest, but the vigorous growth of output and employment in 1983-84 are not.

The fourth section is devoted to an analysis of the importance of market expectations about monetary policy. Much evidence on the behavior of market expectations was created by the Federal Reserve's introduction of new monetary control procedures in October 1979, and there is a substantial body of research to review. The fifth section of the paper contains an evaluation of the contribution of monetary policy to the disinflation of the $1980 \mathrm{~s}$. In the 
sixth and final section I conclude with some comments on the implications of the previous sections for the debate on monetary rules.

\section{THE DECLINE OF VELOCITY AFTER 1981}

At least for most monetarists, and I believe for most Keynesians also, the behavior of velocity after 1981 was a surprise, and there is much to be learned, or relearned, from understanding why. Because the majority of economists have traditionally favored $M 1$ and because the issues $I$ discuss are not peculiar to $M 1$, I will confine my analysis to $M 1$ and $M 1$ velocity, and not take up the issue of whether definitions of money other than M1 should be employed.

The standard money demand function. The money demand function was the subject of an enormous amount of work in the 1960s and 1970s. Most economists settled on a formulation that made real money demand $M / P$ a $\log$ linear function of real income $y$ and one or more interest rates $R$, as in eq.(1) below. The money demand function was often stated in velocity form, as in eq. (2).

(1) $\log (M / P)=-b_{0}+b_{1} \log (y)-b_{2} \log (R)$

(2) $\log (V)=\log (y P / M)=b_{0}+\left(1-b_{1}\right) \log (y)+b_{2} \log (R)$

Most quarterly specifications included a lagged adjustment mechanism of some sort, with the Koyck form most often employed. There was general, though not unanimous, agreement that $M 1$ was the most appropriate monetary aggregate and that one or more short-term interest rates worked better than a long-term interest rate. It appeared that the interest elasticity $b_{2}$ was relatively low (in absolute value), perhaps in the neighborhood of $0.15-0.25$. It also appeared that the real income elasticity $b_{1}$ was somewhat below unity, perhaps in the neighborhood of 0.6 to 0.8 .2

Confidence in the stability of the money demand function began to erode in 1975 as velocity rose more rapidly than could be explained by the standard money demand function. The problem was "The Case of the Missing Money," 
which was the title of a paper by Goldfeld (1976). I believed at the time, and still believe, that estimates of money demand parameters were much less precise than estimated standard errors indicated. ${ }^{3}$ The problem is that an estimation period with an initial year after 1946 -- the initial year for many estimations is 1952 or 1953 -- is dominated by upward drifts in all the. variables that enter the money demand function, as shown in Table 1 which reports a correlation matrix for the relevant variables for 1947.1 to 1986.4 .4 The unreliability of money demand estimates is indicated by the fact that widely differing specifications of regressions explaining velocity or real money balances yield very different income and interest elasticities but only small differences in the regression $\mathrm{R}^{2}$ or standard error of estimate. This point was discussed in the $1970 \mathrm{~s}$, but not enough attention paid to it.

Understanding velocity trends. In the mid $1970 \mathrm{~s}$ a new strand of money demand research arose based on the rapidly developing theory of time series analysis. The pioneering paper was by Gould and Nelson (1974). They showed that velocity over the period from 1867 to 1970 had statistical properties closely resembling a pure random walk without drift. Later work by Nelson and Plosser (1982) showed that most economic time series closely approximate random walks.

In extensive review articles, neither Laidler (1980) nor Judd and Scadding (1982) reference the Gould and Nelson paper. Their reviews reflect the thrust of mainstream money demand research which has been to find economic explanations for changes in velocity. That search is indeed exactly the correct enterprise. Analysis of the time series properties of velocity is not a substitute for economic explanations of velocity but instead provides a statistical base with which economic explanations must be consistent. Rasche (1986) discusses the implications of time series analysis of velocity for structural estimation of a money demand function, but he limits his study to postwar U.S. data.

Analysis of velocity trends has a long history. Irving Fisher argued that improvements in communications and transportation would raise velocity. 5 Milton Friedman and Anna J. Schwartz argued that velocity had a secular downward drift through World War II due to an income elasticity of demand 
for money above unity, and they attributed the postwar rise in velocity to increased confidence concerning economic stability. ${ }^{\circ}$ Many other examples of attention to velocity trends could be cited.

Developments in econometrics theory in the 1970 s suggested that it is dangerous to estimate equations using data subject to significant trends. Thus, authors increasingly worked with detrended data or ran regressions with data in first difference form. For a postwar sample period, using differenced data in a regression with velocity as the dependent variable invariably yields an estimated equation with a statistically and economically significant constant term and a very low interest elasticity. The constant term in the regression picks up the average velocity increase of about 3 percent per year and interest rates add relatively little explanatory power.

Although economists generally hesitate to put a time trend into a regression as an explanatory variable, few seem to worry about leaving a constant term in a first difference regression. This practice is peculiar in that a constant term in a first difference regression is, of course, equivalent to a linear time trend specification in a levels regression. The issue is critical for estimating a money demand function because of the need to determine how much of the postwar increase in velocity should be attributed to rising interest rates and how much to a time dummy.

Table 2 reports very simple $M 1$ velocity regressions using first differences of natural logs of annual data 1916-86. For reasons to be discussed later the interest rate variable in the regressions is Moody's Aaa long-term bond yield and the real income elasticity has been constrained to 1.0 by not including real GNP as a regressor. The sample periods chosen for Table 2 reflect the facts that: a) the end points of the available annual $M 1$ data are 1915 and 1986; b) the peak years for velocity before and after World War II were 1918 and 1981; c) the trough year for velocity was 1946; and d) velocity was almost identical in 1915 and 1957. The regressions cover periods of falling velocity, rising velocity, and unchanged velocity.

Table 2 tells a straight-forward story. When velocity is falling, as from 1919 to 1946, the constant term picks up the negative drift. In fact, for this 
period the interest rate coefficient has the wrong sign and the adjusted $R^{2}$ is negative. When velocity is rising, as from 1946 to 1986, the constant term picks up the positive drift. The interest rate coefficient has the correct sign, but its t-statistic falls short of conventional levels of statistical significance. The adjusted $R^{2}$ is only 0.056 .

For periods when the overall velocity drift is zero, as for 1916-57, the constant term is very small and the coefficient on the interest rate is considerably higher than for the regressions discussed in the previous paragraph. However, the adjusted $R^{2}$ is still very low. The full period 191686 has a slight upward velocity drift. The regression for this period has a higher constant term and lower interest rate coefficient than does the regression for 1916-57. I conclude that the first difference specification with a constant term is defective; parameter estimates are very sensitive to the sample period.

The 1970s research on money demand, and other developments, affected policy advice late in the decade. The research findings, to summarize, included instability of structural models of money demand, low estimates of the interest elasticity, and the apparently highly predictable velocity increase of about 3 percent per year. Other developments included the growing use of time series (ARIMA) forecasting models and the increasing urgency of controlling inflation. A number of economists, myself included, began to base monetary policy advice on two assumptions: first, that velocity would continue to grow at a 3 percent rate and, second, that the interest elasticity was essentially zero.

We committed an avoidable error: in analyzing money demand theory and empirics we insisted on economic explanations for velocity trends, but in analyzing monetary policy we relied on a velocity time trend. The standard money demand function foundered in the mid and late 1970 s and the reliable velocity trend broke down in the early 1980s. Where does all this leave us? 


\section{REPAIRING THE MONEY DEMAND FUNCTION}

The first thing to say is that it is hopeless to attempt to resolve uncertainties about money demand through analysis of postwar U.S. data; the multicollinearity problem is overwhelming. Second, transforming the data to first difference form yields, I believe, a serious underestimate of the interest elasticity of demand. Let me now explore this second point.

Figure 3 shows M1 velocity, the commercial paper rate, and the Aaa bond yield for annual data $1915-86$ plotted on a ratio scale. Velocity is an extremely smooth series compared to the two interest rate series. There has been a long debate over which interest rate to use in the money demand function, but on the face of it the long rate would seem to have the edge. The short rate simply looks too volatile.

The lagged adjustment model is the usual way to reconcile the relatively low volatility of velocity with the relatively high volatility of the short interest rate. Goldfeld (1973) estimated an adjustment speed of 25-30 percent per quarter. However, with annual data the conventional adjustment lag argument is not convincing. Why should economic agents hold idle money balances when non-monetary assets bearing a higher interest rate are so readily available?

The case for the long rate. Table 3 reports annual velocity regressions in which the income elasticity is constrained to be 1.0 (for reasons discussed later). These regressions yield a much higher estimate of the interest elasticity for the long rate than for the short rate. Many others have found this same result but, strangely, no one seems to have been puzzled by it. Under the expectations theory of the term structure of interest rates the long rate is a weighted average of expected future short rates, and consequently the full-adjustment (or long-run) interest elasticity with respect to the long rate ought to equal that with respect to the short rate.

To see this point, suppose an economy operates for a long time with zero inflation and short and long rates in the neighborhood of 3 percent, and then adjusts to a long-lasting inflationary equilibrium with an inflation rate of 10 
percent and short and long rates in the neighborhood of 13 percent. Using these hypothetical data, estimates of the interest elasticity from short rates and from long rates should be identical because both rates have risen by the same amount.

Now consider an actual estimation. If the sample period is long, and if the general level of rates changes significantly over the sample, the correlation of short rates and long rates will be very high. For annual U.S. data 1915-86 the correlation between the logs of the two rates in Figure 3 is 0.868. The estimated interest elasticity of money demand ought not to depend very much on which interest rate is used in a regression.

In fact, in the regressions in Table 3 the long rate not only yields an estimated elasticity twice the elasticity of the short rate but also a higher $R^{2}$. I conclude that the long rate rather than the short rate belongs in the money demand function. The short rate yields a lower interest elasticity because the short rate measures the true opportunity cost variable with error.?

It should be emphasized that this errors-in-variables argument could go either way. The fact that the short rate has a higher variance than the long rate does not automatically mean that the short rate will have a lower regression coefficient. ${ }^{8}$ If velocity were in fact a function of the short rate, then velocity would be much more volatile than it is. In this case the long rate could yield a lower regression coefficient than the short rate because the long rate would measure the short rate with error.

The argument rationalizing the better fit of the long rate is that changes in the amount of money held relative to income require that economic agents make capital investments of various kinds in order to economize on money. For example, to reduce cash balances a corporation may have to invest in personnel and computers. Banks may open new offices to reduce travel time ("shoe-leather costs") for their customers. These investments will not be undertaken unless an increase in interest rates is judged to be permanent -long-lasting enough relative to the life of the investment. Nor will a decline in interest rates judged to be transitory lead agents to abandon past investments that economize on the holding of money. The long-term interest 
rate reflects expectations about future short-term interest rates, and so measures the appropriate cost variable in the money demand function more accurately than does the short-term interest rate. Although the long rate, on this argument, is the appropriate cost variable for the money demand function, in managing money balances agents may well be switching between money and short assets. 9

Money as a buffer. The usual conception of money demand is that the error term in a money demand function is independent of other variables and disturbances in the system of equations describing the economy. Such a disturbance must be cleared through a change in one or more endogenous variables in the system. A money demand disturbance will have the same effect on the system as would a shift of the same size in the constant term of the money demand equation.

The buffer stock view of money demand has very different implications. In the short run money is a "slack" variable that absorbs disturbances originating elsewhere. Part of an agent's money balance at any given time reflects what Keynes called the "precautionary motive" for holding money. Another part reflects a particular realization of net cash flows from other activities which leave an agent's money balance transitorily high or low. Milton Friedman's phrase, "a temporary abode of purchasing power," carries the right flavor. On a formal level, the stochastic inventory model by Miller and Orr (1966) rings true to me.10

The implications of the buffer stock model can be seen by examining several examples. Suppose the central bank increases the money stock unexpectedly through an open market operation. In Figure 4, the initial money demand function is LO, and we assume that the money stock jumps from MO to M1. The private sector holds more money and fewer bonds than before. However, in the absence of any other disturbance there is no reason for anyone to do anything in the short run. Agents do not know the source of the extra money and have no reason to believe that the disturbance is permanent. Consequently, in the short run the interest rate remains at $R 0$ and the flow of spending does not change. 
The econometrician, however, interprets this case as involving a disturbance $U 1$ to the money demand function shifting it from LO to L1 and assumes that $U 1$ is independent of the increase in the money stock. That interpretation is the only conventional way to reconcile the observation of a money stock of $M 1$ with the interest rate of $R 0$. Because the money demand disturbance is interpreted as independent, the analyst may conclude that it is very fortunate that the central bank accommodated the disturbance; if it had not done so, then the interest rate would have risen to $R 1$.

For another example, suppose there is a jump in GNP due to a good harvest. It is not necessary for agents to hold more money to finance the larger GNP for they already hold a buffer for just such eventualities. To the econometrician there has been a downward shift in the money demand function; GNP has risen, which should have been associated with higher a real money stock and/or higher interest rate, but in fact neither the money stock nor the interest rate has changed. The economist using this conventional model, which includes the assumption of independence of money demand and money supply disturbances, would believe that if the central bank had coincidentally increased the money stock there would have been a double stimulus to aggregate demand -- from the money demand disturbance and from the increase in the money stock. However, under the buffer stock view of money demand the apparent disturbance to money demand would not have been observed in the first place if the central bank had just by chance increased the money stock at the time of the good harvest.

The buffer stock view is closely related to Milton Friedman's conception of money demand as a function of permanent magnitudes. Transitory changes in, say, output are not accompanied by changes in the amount of money that agents want to hold. The problem with this conception of money demand, at least as some have interpreted it, is that it requires that exogenous changes in money supply be cleared by changes in the permanent variables such as permanent income that enter the money demand function. That implication is not necessary in the buffer stock model because changes in money supply are willingly held in the short run without there being repercussions in other markets. 
Refer to Figure 4 again to consider a case in which new information -such as election results, a policy announcement by the government, or a statistical release reporting last month's increase in the money stock -- leads the market to bid up interest rates. The initial equilibrium has money demand function LO, money stock $M 0$, and interest rate $\mathrm{R} 0$. The interest rate rises instantaneously to $\mathrm{R} 1$ when the market receives new information, but at this instant the money stock does not change. On the conventional view of money demand there has been a money demand disturbance UI equal to the horizontal distance between money demand functions $L O$ and $L I$ and this disturbance has been cleared through the increase in the interest rate to $R 1$.

Surely, however, if the central bank had coincidentally increased the money stock by the size of this disturbance -- that is, from MO to M1 -- the interest rate would have gone up anyway to clear the credit markets in the wake of receipt of new information. If the coincidental increase in the money stock had in fact occurred the conventional view would be that a money demand disturbance U2 had shifted the money demand function from LO to L2. That is the only possible conventional interpretation to rationalize an interest rate of $\mathrm{R} 1$ and a money stock of $\mathrm{M} 1$. An observer holding to the conventional view of independent money demand disturbances will believe that it is highly desirable that the central bank followed an accommodative policy permitting the money stock to rise to $M 1$, for otherwise the disturbance (which is really a credit market disturbance) shifting the money demand function to L2 would have pushed the interest rate up to $\mathrm{R} 2$.

The only way, to my knowledge, to represent this analysis in a formal system of equations is to assume that the disturbance in the money demand equation is correlated with variables and/or disturbances in other equations. In the examples discussed above money demand disturbances are correlated with variables and/or disturbances in the credit market and with money supply disturbances. ${ }^{11}$

This model leaves the econometrician in a difficult situation. There is no obvious way to estimate the aggregate money demand function to get around the problem that money demand disturbances are correlated with other variables and disturbances in the system. Moreover, because expectations 
(rational or otherwise) affect interest rates all information relevant to expectations is likely to be correlated with the money demand disturbances identified by the econometrician. Finally, the adjustment process through which departures of money balances from long-run equilibrium levels have effects on the endogenous variables in the money demand function is likely to be highly variable.

These problems seem likely to be especially serious when estimating regressions in first difference form. A substantial part of the variance of quarter-to-quarter and year-to-year changes in interest rates reflects disturbances elsewhere in the economy that are correlated with (conventionally-defined) money demand disturbances. The effect is to produce a substantial bias toward zero in the estimated interest elasticity of money demand in a first difference equation.

In a levels regression the noise in the interest rate is smaller compared to the systematic part of the rate, and so the bias in the estimate of the regression coefficient is less than in a first difference regression. However, in a levels regression the residuals are highly serially correlated creating two problems for the problem at hand. The first is that the estimates of the standard errors are biased downward. That is not too serious an issue because under usual assumptions the coefficient estimates themselves are not biased. However, if the residuals are in fact generated by a random walk the levels regression may yield biased coefficient estimates. With a random walk, even one without drift, the mean of the levels residuals is unlikely to be zero and may be time-dependent.

Suppose the true money demand residuals starting with the first observation (1915) accumulate so that the last observation (1986) has a residual that is positive and relatively large. The true mean of the residuals is positive, but the estimated regression will have coefficients such that the estimated residuals have a zero mean. Thus, in a levels regression the ex post drift in the residuals will be assigned to any variable in the regression that has a drift (up or down) over the sample period. 
Consider a levels regression with velocity as the dependent variable. If the residuals are correctly modeled as a random walk, and if they have an upward (downward) drift over 1915-86, then the interest rate will have an upward (downward) biased coefficient because the rate rose over this sample period. One way to avoid this bias is to use a sample period for which the interest rate is about the same at both ends. Thus, in Table 3 the interest elasticities estimated from the Aaa bond rate over 1915-64 and 1920-68 are least likely to be biased. From these results $I$ conclude tentatively that the interest elasticity of demand for real money balances is about 0.6 in absolute value.

Although there is some protection against bias in the estimate of the interest elasticity from using sample periods in which there was no overall increase or decrease in interest rates, that protection is not available when trying to estimate the income elasticity because income almost always rises. In working on this paper I made no effort to estimate the income elasticity of money demand because I am not convinced that I could learn anything from the attempt. It seems likely that convincing evidence on the income elasticity will have to come from studies using micro data and country cross section data. ${ }^{12}$

Other money demand issues. It remains an open question as to whether the best definition of money in the United States is M1, M2, or some other M. Various Ms are highly correlated with each other over long periods, and it seems probable that there is no way to extract from time series data the answer as to which $M$ is best. This issue should be reexamined, but it seems much less important than the interest elasticity and velocity trend issues discussed above.

An even more difficult issue is that of the short-run adjustment mechanism. The approach underlying the standard money demand function relies on a model of adjustment by an individual agent who brings actual balances into line with desired balances. The problem is that this model, whether in Koyck or distributed lag form, does not invert properly to the case in which exogenous changes in the money stock yield lagged adjustments in the arguments of the money demand function -- in the price level, nominal 
interest rates, and real GNP. Because most central banks follow an accommodative policy in the short run, some of the data are generated by a process in which the aggregate money stock adjusts passively over time to changes in the arguments. However, the data also include observations in which the money stock changes actively and prices, incomes, and interest rates adjust over time.

There is no obvious way to extract from the data these different types of adjustment. Here, even micro data may be of little assistance because macro lags may arise from the accumulation of relatively short lags at the micro level. Moreover, in the context of macroeconomic modelling, adjustment mechanisms are almost certain to be unstable for the reasons detailed by Lucas (1976) in what has come to be called the "the Lucas critique."

To summarize these thoughts about money demand, experience in the 1980 s fits a model with a considerably higher interest elasticity than was generally accepted a few years ago. A reexamination of annual data back to 1915 supports this view. The case for the long-term interest rate appears stronger than the case for the short-term rate. Most importantly, time trends with a few breaks fit the velocity data very well but time is in fact a totally unreliable explanatory variable. Time has a seductive but dangerous appeal as an explanatory variable because velocity is a much smoother variable than most regressor candidates. Finally, no one has constructed a convincing model of lagged adjustment and we must conclude that we know essentially nothing about adjustment speeds -- except that they are faster during hyperinflations than at other times -- and nothing about the stability or regularity of adjustment mechanisms.

\section{THE REAL RATE OF INTEREST}

The behavior of the real rate of interest in the $1980 \mathrm{~s}$ has been every bit as much a surprise as has the behavior of velocity. Fama (1975) argued that the ex ante real rate is a constant. Few economists accepted that hypothesis as literally true, but the evidence did support the proposition that most of the variance of nominal short-term interest rates reflected variance in inflationary expectations rather than variance in the expected real rate of interest.13 
Depending on the choice of short-term rate, for 1953-73 the real rate was 1 to 2 percent and for 1973-78 was 0 to -2 percent. For 1980 to 1985, however, the real rate -- both ex ante and ex post -- was in the 4 to 8 percent range. These rough figures are satisfactory for the purpose at hand; everyone agrees that real rates were dramatically higher in the early 1980 s than they were during the previous several decades. ${ }^{14}$

In 1981-82 it was logical to attribute high real rates to monetary stringency, just as it was logical to attribute abnormally low real rates in the late 1970 s to monetary laxity. On this interpretation no new lesson for monetary policy arose from either experience. The period of accelerating inflation and abnormally low real rates in the late 1970s would not have occurred if the Federal Reserve had held money growth to, say, 4 percent per year. The deceleration of money growth and high real rates in 1981-82 would not have occurred if the inflationary monetary policy of the late $1970 \mathrm{~s}$ had not occurred. Or, taking the initial conditions of 1980 as given, a more gradualist monetary policy in 1981-82 would presumably have yielded a smaller increase in real rates and a more shallow recession than the one actually experienced.

Real determinants of the real rate. Whatever may be the validity of the monetary explanation for high real rates 1981-82, that explanation did not fit the conditions following the recession trough in late 1982. Most Keynesians predicted a slow recovery from the recession because real rates of interest were higher in the early 1980s than at any time since the onset of the Great Depression. In the past high real rates have almost invariably been associated with recession and falling prices, as in 1929-32, 1920-21, 1907, and 1893-94. (See Figure 2.) The combination of high real rates and vigorous cyclical expansion during 1983-84 and continuing, though slow, expansion 1985-86 is very unusual in the light of U.S. experience over the past century. The high real rates during 1983-85 almost certainly reflected one or more real disturbances, and the case for a real explanation is reinforced by the behavior of the real exchange rate.

Figure 5 shows the real exchange rate from January 1975 to April 1987 on a base of January $1985=100$. For 1983-85, the behavior of the real economy, of the real exchange rate, and of the real interest rate are simply 
not consistent with a monetary explanation. Indeed, the monetary explanation for 1981-82 may have to be supplemented given that the real rate of interest was abnormally high by the standards of previous postwar recessions, although not by the standard of 1929-32.

What were the real disturbances? I favor the view that the primary real disturbance was the 1981 change in U.S. tax law which had the effect of substantially increasing the real after-tax rate of return on new business investment. Others hold to the view that the substantial federal budget deficit that began in 1981 and continues to this writing is responsible.1s For the purpose at hand, the source of the real disturbance is irrelevant. There was a real disturbance, and it was large.

Another much-discussed class of real disturbances is the "supply shock," and there is a substantial literature on energy, food, raw materials, exchange rate, productivity, and other shocks of the 1970s. Such shocks reduce output and the real rate of interest, and raise the price level.16 However, a monetary hypothesis competes with the supply-shock hypothesis for explaining the 1970s because the alleged supply shocks occurred at times when the economy was stressed by accelerating money growth. Monetary policy was clearly inflationary in 1972-73 before the Mideast War and OPEC oil shock of October 1973, and again in 1977-78 before the overthrow of the Shah of Iran and the second oil shock in 1979. In both episodes inflation was unambiguously rising before the oil shocks.

My own position is that real disturbances are much over-rated as a source of the problems of the 1970s, and that the real effects of inflationary monetary policy are much under-rated. On this view the supply shocks would have had relatively modest effects if they had occurred in an economy characterized by both general price stability and confidence in that stability. Inflationary monetary policy made the economy vulnerable to bad news; the shocks surely were themselves a problem but their main significance was to trigger the inflationary bomb that was bound to go off anyway. 
Monetary policy implications of real disturbances. The issue of the appropriate monetary policy response to a real disturbance, either through a discretionary policy adjustment or through a monetary rule which has a response built in, is too large to be discussed satisfactorily here. But the dimensions of the problem are larger than I had previously thought. My. estimate of the magnitude of conceivable real rate disturbances in the U.S. economy has risen and so also has my estimate of the interest elasticity of money demand.

Suppose the U.S. economy in 1981 had been operating at a stable and low inflation rate and reasonably close to full employment. Suppose a disturbance had raised the real rate of interest by roughly the magnitude actually observed, and that as a consequence nominal interest rates had risen from 4 percent to 8 percent. This doubling of nominal rates is a logarithmic increase of 0.7 , and multiplying by an interest elasticity of money demand of 0.6 yields a logarithmic change in velocity of 0.42 , or 50 percent. That is a very large velocity disturbance, and one that would obviously have a considerable impact on both the real economy and the price level in the absence of a change in the money stock.

These calculations may provide a misleading picture of the magnitude of the problem because there is evidence that the real rate and the expected rate of inflation are negatively correlated. That is one of the findings in Fama and Gibbons (1982). More casually, real rates fell in the late 1970s as inflation expectations and nominal rates rose, and real rates rose in the early $1980 \mathrm{~s}$ as inflation expectations and nominal rates fell. In these two instances, then, inflationary expectations changed by more than the real rate so that the real rate and the nominal rate moved in opposite directions rather than in the same direction as assumed in the preceding paragraph.

The key issue here is whether the observed negative correlation between the real rate and inflation expectations is a accident of history or is embedded in the structure of the economy. The correlation almost certainly depends on whether real disturbances over a particular period originate primarily on the demand or the supply side of the economy and on whether a country has a fixed or floating exchange rate. ${ }^{17}$ 
To summarize, there is unmistakable evidence that a large real shock occurred in the early 1980s. There may also have been significant real shocks in the 1970s, although monetary shocks may be the larger part of the explanation. In any event, recent experience of inflation and disinflation in the United States suggests that monetary policy should be formulated in. such a way as to deal with the possibility of large real disturbances. Put another way, there is more to monetary policy than simply avoiding monetary disturbances, as important as that aspect of policy must obviously be.

\section{MARKET EXPECTATIONS $\underline{\text { CONCERNING MONETARY POLICY }}$}

Both interest rates and money growth became more volatile after the Federal Reserve changed its operating procedures in October 1979. After October 1979 it became immediately apparent to the most casual observer that market interest rates reacted quickly to weekly reports of money stock data every Thursday afternoon (Friday afternoon for part of the period under review). One useful outcome of the experience was a greatly improved understanding of market responses to monetary policy.18

To understand the issues here it is best to think of Fed policy day by day as involving an adjustable peg for the federal funds rate. That description of Fed policy is certainly correct before October 1979, is approximately correct after October 1982, and is in dispute for the period between. If this model is accepted for the entire period, then market responses to receipt of information provides evidence on the market's evaluation of the factors that lead the Federal Reserve to adjust its federal funds rate peg.

Effects of unexpected money. Investigators have partitioned each week's money stock data release into expected and unexpected parts. The expected part is based on a survey of market participants conducted by Money Market Services every week prior to release of money stock data. The interest rate response has been measured over 24 hours spanning the announcement time, and over the period from $3: 30 \mathrm{pm}$ to $5: 00 \mathrm{pm}$ spanning the announcement time. 
Although the data contain some anomalies, the basic finding is that the market responds to the unexpected part of the money stock data release. The response was far greater during the period from October 1979 to October 1982 than either before or after. The decline in the response is no doubt due to the fact that the Federal Reserve increasingly deemphasized money stock control after October 1982. There is a documented decline in the response through September 1985, and my casual impression is that the response fell essentially to zero in 1986.

The magnitude as well as the existence of the interest rate response to money announcements is important. Roley and Troll (1983) and Roley (1986) estimate that an unexpected increase of $\$ 1$ billion in the money stock raised the Treasury bill rate by a trivial 1.6 basis points from October 1977 to October 1979, by 10.4 basis points from October 1979 to October 1982 , by 3.4 basis points from October 1982 to February 1984, and by 1.4 basis points from February 1984 to September 1985.

These estimates of the effects on the bill rate of an unexpected change in the money stock can also be used as an estimate of the effect of the expected change in the money stock. As information accumulates day by day the market will adjust its expectation of the change in the money stock, and will presumably bid the bill rate up or down to the same extent as the documented effect from unexpected changes in money. More precisely, the relevant measure is the market's expected change in the money stock less its guess as to the Federal Reserve's desired change in the money stock.

This discussion has assumed that the market's response to money stock data arises from speculation on future monetary policy rather than from the effects of money growth on the market's expectation of future inflation. This proposition is supported by the way in which the interest rate response to money growth changed over time as the Federal Reserve changed its operating procedures. However, the strongest evidence supporting this proposition arises from an examination of the response of the exchange rate to unexpected money. Engel and Frenkel (1984) studied data for October 1979 to August 1981 and showed that dollar appreciated (depreciated) against the German mark in response to an unexpected increase (decrease) in the stock of money in the 
United States. This finding is consistent with the hypothesis that the interest rate response to unexpected money is a real rate response. If the inflationary anticipations argument were correct the exchange rate should have depreciated in response to unexpected increases in the money stock.

I know of no study that sorts out the effects on interest rates of actual changes in the money stock as distinct from announcements of past changes. If I am correct that actual changes have little or no immediate effect on interest rates, then rates were much more volatile after October 1979 both because the market's response coefficient to unexpected money was higher and because money growth was less stable and less predictable than it had been before. Thus, the market's increased response to announcements of money stock changes after October 1979 would not have created increased interest rate volatility had the Federal Reserve been successful in stabilizing money growth. The issue is not a minor one; the effect of the Fed's October 1979 procedures on interest rate volatility, which shows up dramatically in interest rate charts, had much to do with the Fed's abandonment of efforts to control money growth.19

Although there is a dispute concerning the Fed's technical capacity to stabilize short-run money growth there is no doubt whatsoever that the Fed can control nonborrowed bank reserves extremely precisely. The evidence strongly suggests that if the Fed were to pursue an announced policy of achieving a bank reserves target, and were to hit the target with a small margin of error, then the unexpected part of monetary policy would have minimal variance and interest rates would not be bid up or down by speculation on Fed actions to offset the error in hitting its announced target.

Effects of other information. There is also evidence of a dramatic change in October 1979 in the market's response to adjustments in the Federal Reserve's discount rate. Using data for the two-year period before and the three-year period after October 1979, Roley and Troll (1983) report that per 100 basis points increase (decrease) in the discount rate the bill rate rose (fell) 10 basis points in the first period and 54 basis points in the second period. 
This finding is something of a puzzle. Historically, the discount rate has followed money market rates and there is no good reason for the discount rate to have a separate influence on those rates. Particularly after October 1979, discount rate changes ought not to have affected market rates at all if the Fed had been controlling bank reserves to achieve money growth targets and letting market rates of interest go wherever market forces took them. Given a money growth target, the discount rate could affect the division of total bank reserves between borrowed and nonborrowed reserves but not, presumably, either the level of total reserves consistent with target money growth or the level of interest rates consistent with target money growth. In this model any change in the bill rate for any reason ought to have carried with it the assumptions that the discount rate would follow (and so the market would fully expect discount rate changes when they actually occurred) and that the discount rate would not have any independent influence on market rates anyway.

The only way to make sense of the observed effect of the discount rate on market rates is to assume that the Federal Reserve has persistent interest rate targets. Before October 1979 the Fed changed its federal funds rate target by a relatively small amount at a time and a discount rate change announced to the market that the Fed had changed its funds rate target. After October 1979 the Fed was much more aggressive in changing its funds rate target and so the market's response to discount rate changes was much larger. This response shows that the market believed that the Fed was concerned either with the level of discount window borrowing per se, or with the level of market interest rates, or both. On this interpretation, Fed policy after October 1979 did not involve a target path for bank reserves that was exogenous to short-run fluctuations in money market interest rates. Instead, Fed policy must have involved aggressive use of the federal funds rate as the policy instrument. The Fed adjusted the funds rate on the basis of the observed money stock and other data and discount rate adjustments signalled changes in the target zone for the funds rate.

Roley and Troll (1983) and Roley (1986) also provide evidence on the effect on the bill rate of the unexpected component in official releases of data on inflation, unemployment, and industrial production. The estimated effects 
are all statistically insignificant except for the industrial production index in the period from February 1984 to September 1985. These results may understate the importance of data releases because monetary policy tends to be asymmetric. My hypothesis is that when inflation is the major concern of the public the Fed will tend to push up interest rates in response to reports of high inflation, high employment growth, and growing industrial production but will tend not to push interest rates down in response to reports in the opposite direction. Similarly, when recession is the major public concern the Fed will tend to push interest rates down in response to low inflation, falling employment, and falling production but will tend not to push rates up in response to reports in the opposite direction. ${ }^{20}$

Effects of market expectations on policy. From this evidence it is clear that the market is extremely sensitive to the manner in which the Federal Reserve conducts policy. There should be no surprise that in the winter and spring of 1987 the market began to look especially closely at commodity price indexes as concerns developed that inflation might rise significantly. Recent appointees to the Board of Governors have suggested that commodity prices be used as a key indicator of the appropriate stance of monetary policy. On this view, monetary policy should become more restrictive when commodity prices are rising; what that means in practice is that the Fed should push money market interest rates higher.

These considerations raise a serious issue concerning how the Federal Reserve should interpret observed interest rate changes. Suppose, for example, that the Treasury bill rate rises in response to a report of higher commodity price inflation. If the Fed holds its target for the federal funds rate unchanged, and does so systematically in such cases, the market will learn that the Fed does not in fact change its funds rate target in response to commodity price information. In time the bill rate will cease responding to commodity prices. At the opposite extreme, the Fed may ratify the market by adjusting the funds rate by an amount that matches the market's adjustment of the bill rate. In this case the Fed would simply follow the market, which would be an obviously unsatisfactory and ill-defined monetary policy. 
If the Fed develops a systematic policy response to receipt of new information, then changes in market interest rates upon receipt of new information or upon market forecasts of future data releases will reflect nothing more than the market's judgment of the Fed's response function. The Fed cannot then use interest rate changes to provide information on disturbances elsewhere in the economy.

It is important to understand that the problem here is not just a "practical" one. It is in principle impossible to extract useful information about the private economy from any variable the Fed itself controls. No one would dream of trying to extract information about the private economy from the behavior of the discount rate. Nor should anyone try to extract information about the private economy from the behavior of the federal funds rate when that rate is closely controlled by the Federal Reserve, as was true before October 1979 and after October 1983.

Of course, the bill rate and other longer-term rates reflect market expectations concerning both future data and the Fed's responses to the data. The point remains, however, that the Fed cannot extract from interest rates information about the economy without knowing market expectations concerning Fed policy. In fact, the principle holds for all speculative prices. The prices of storable goods -- commodities, land, securities, etc. -- reflect in part expectations of future monetary policy because speculators know that Fed actions will influence aggregate real demand and the general price level.

In sum, interest rates -- whether nominal or real -- are a very poor guide to monetary policy. Interest rates respond to disturbances in the real economy, to disturbances in money demand, and to changes in market expectations of future monetary policy. Recent studies have made clear that market expectations concerning policy have economically significant effects on interest rates. This fact ought to be factored into the design of monetary policy; the issue is explored briefly in the final section of the paper on monetary rules. 


\section{THE ROLE OF MONETARY POLICY IN $\underline{\text { REDUCING INFLATION }}$}

Monetary policy played a critical role in reducing inflation in the early 1980s, but quantifying the contribution would go beyond the scope of this paper. The issues involve the direct contribution of lower money growth, the contribution of changed inflationary expectations, and the contribution of real disturbances.

Role of lower money growth. In the late 1970s inflation rose to a higher rate than would have been sustained in the long run by the rate of money growth at that time. On an annual average basis, $M 1$ growth peaked at a little over 8 percent in 1978. Assuming secular growth of real GNP of about 3 percent per year, sustained M1 growth of 8 percent per year would yield secular inflation of 5 percent per year if velocity has zero secular increase and 8 percent inflation if velocity has a 3 percent secular increase. Actual inflation on an annual average basis as measured by the fixed weight GNP deflator was 9.3 percent in both 1980 and 1981 .

Thus, at least one and perhaps four percentage points of 1980-81 inflation were due to the acceleration of money growth in the late $1970 \mathrm{~s}$ and/or the oil price shock of 1979. Ending the acceleration of money growth was part of monetary policy, but the effects of changing money growth should be distinguished from those of the rate of money growth itself.

Money growth fell in the early 1980s, and here again it is necessary to distinguish the effects of the deceleration from those of the lower rate itself. On an annual average basis, M1 growth fell to 6.5 percent in 1981 , rose to 9.8 percent in 1983, and fell back to 6.0 percent in 1984 . Inflation as measured by the fixed weight deflator fell to slightly less than 3 percent in 1986 . On the assumptions of secular real GNP growth of 3 percent per year and zero secular change in velocity, sustained M1 growth of 6 percent per year would yield sustained inflation of 3 percent per year. However, when the data are averaged over several years it is clear that in the 1980s inflation fell much more than did M1 growth. 
On a qualitative level, the decline of inflation after 1980 is perfectly consistent with the deceleration of money growth but the magnitudes seem wrong. Although $M 1$ growth did fall in 1980-81, its average rate over the 1979-84 period was essentially identical to its average rate over the 1975-79 period. It seems to me to be unreasonable to argue that monetary conditions alone can account for the extent and duration of the decline of inflation.

Role of inflationary expectations. One way to reconcile the sustained reduction of inflation $1982-86$ is to accept the hypothesis that inflation expectations declined substantially from their level in the late 1970s. Without question, inflation expectations did decline, and the Federal Reserve's willingness to maintain a restrictive policy long into the 1981-82 cyclical contraction must have had something to do with the decline.

But it is difficult to attribute the durability of the decline in inflation expectations entirely to monetary policy. ${ }^{21}$ It is illogical to argue that the market was simply relying on Fed Chairman Paul Volcker for it was unclear whether he would be reappointed in 1987 to another term as Chairman, and in the event he was not reappointed. What was clear was that the Reagan administration had ceased to be concerned with inflation, as evidenced most clearly by the administration's policy starting in September 1985 to depreciate the dollar on the foreign exchanges. It was also clear that Congress and the administration both had an incentive to inflate in order to relieve pressures arising from the large federal budget deficit.

In sum, it appears that significant weight must be accorded to nonmonetary conditions as shaping both the actual inflation rate and inflation expectations from 1981 through 1986. The obvious candidates for these nonmonetary conditions are those responsible for the high real rate of interest 1982-85.

Role of non-monetary conditions. As mentioned earlier, there is substantial disagreement as to the causes of high real rates of interest in the United States 1981-85. However, there is agreement that the high real rates were primarily responsible for the real appreciation of the dollar, which reached its peak in February 1985. The strong dollar almost certainly had 
much to do with the rapidity of the decline of the overall inflation rate in 1982 and its further decline in 1986. Traded goods prices enter directly into price indexes, and also affect the prices of competing non-traded goods. Over the five years from 1981 to 1986 the fixed weight imports deflator fell by 9 percent while the fixed rate exports deflator rose by only 6 percent.

It is often argued that the decline of inflation in 1986 was due to an exogenous oil price decline, but this argument seriously underestimates the importance of the strong dollar. Consider in the abstract a commodity traded in world markets, and ask what happens when currency A appreciates in real terms against currency $B$. In general, the commodity's price should fall in terms of currency $A$ and rise in terms of currency $B$, with the price changes depending on relative supplies and demands and their elasticities in countries $A$ and $B$.

As the dollar appreciated after 1980 the OPEC oil cartel was able to maintain a relatively unchanged dollar price of oil, with the result that oil prices rose very substantially in non-dollar currencies. That outcome would not have occurred in a highly competitive oil market; however, neither was the outcome a profit-maximizing one for a cartel. Whether or not the OPEC cartel weakened in the 1980s, a decline in the dollar price of oil was a predictable consequence of substantial dollar appreciation. Given appreciation of the dollar, OPEC changed the timing of the decline of dollar oil prices but did not determine the decline itself.

In sum, there is good reason to believe that non-monetary conditions contributed significantly to the reduction of U.S. inflation in the $1980 \mathrm{~s}$. However, it should be emphasized that these conditions were inherently transitory. The United States could not expect continuing increases in its real rate of interest and in the real value of its currency. Once these conditions stabilized their contributions to reducing inflation would end and monetary fundamentals would dominate the outcome. 


\section{IMPLICATIONS OF RECENT EXPERIENCE FOR MONETARY RULES}

In past debates on monetary rules no clear distinction has been made between the application of a rule in a situation of stable initial conditions and the application in a period of high inherited inflation. Opponents of a monetary autopilot seem to assume that the economy is always like a ship in a crowded channel while proponents seem to assume that the economy is always on the high seas.

A monetary rule in the steady state. Suppose money growth were constant at, say, 3 percent per year. What would be the operating characteristics of the economy once the transition to the rule was complete?

As argued earlier, recent experience suggests that the interest elasticity of the demand for money is high enough that real disturbances have a substantial potential to raise or lower the inflation rate and to push real growth above or below its equilibrium path. The relatively high elasticity also means, however, that independent disturbances to money demand will have less effect on nominal GNP than would be the case with a lower elasticity.

The buffer stock model of money demand requires a reinterpretation of past evidence on money demand disturbances. If it is true that these disturbances, as conventionally measured, are often dependent on disturbances elsewhere in the economy, then money demand behavior is far more stable and stabilizing, though less rigid, than many have come to believe. Conventionallymeasured money demand disturbances do not provide evidence supporting discretionary monetary policy designed to offset them; such disturbances often reflect money supply disturbances, which have effects of the type emphasized by rational expectations models.

Evidence on the behavior of interest rates under varying monetary policy operating procedures confirms the validity of the general point emphasized in the Lucas critique that parameters in macro model equations will not be stable because these equations are not truly structural. Estimated macro models do not provide any evidence whatsoever on how an economy would operate under a constant money growth rule, and that point will remain even if the money 
demand function in macro models is altered as I have suggested. My guess is that the only evidence that will be very persuasive will be that from actual experiments with a money growth rule because we will not in the foreseeable future be able to extract truly structural equations from data generated under present monetary arrangements.

A monetary rule for disinflation. The monetary rule most of ten advocated for bringing inflation down from an excessive rate is that of gradual, predetermined reductions in money growth. In the late 1970s a number of economists, myself included, advocated a gradualist monetary policy of this type, but I now believe that experience 1980-85 has demonstrated quite decisively that the gradualist prescription is unreliable. The decline of velocity was far greater than economists had predicted, and it seems very unlikely that the economy could have adjusted satisfactorily if money growth had been reduced by, say, one percentage point per year starting in 1980.

The reasoning behind this conclusion may be stated briefly. ${ }^{22}$ Start with a provisional assumption that under a policy of gradualism velocity in the 1980s would have followed the course actually observed. If money growth had declined gradually, then by 1985 nominal GNP would have been falling. Thus, if real growth had been positive in 1985 the price level would have been falling. Nominal interest rates would presumably have been lower than those actually observed, and so velocity would, if anything, have declined even more than its actual decline. It seems very unlikely that real growth could have been positive in these circumstances; the magnitude and speed of the adjustment from the inflationary era of the 1970 s could not have proceeded rapidly enough to permit real growth.

This argument is very casual, and it depends almost entirely on my feel for the data, which I believe many others share in this case. A less casual observation, though, is that there is certainly no precedent suggesting that the real economy could have adjusted without a recession much deeper and more prolonged than the recession actually experienced. Under the scenario of the preceding paragraph the decline of the inflation rate between 1980 and 1985 would have been greater than the decline of inflation between 1928 and 1932.23 
There is a serious and probably insurmountable problem to designing a predetermined money growth path to reduce inflation. When policymakers make a commitment to lower inflation they should expect that velocity growth will decline, and perhaps become negative, if the policy is successful. The pace of adjustment in financial markets and the real economy will depend on expectations concerning future monetary policy and future inflation. If the market expects lower inflation, then inflation will decline without a decline in money growth. Under these circumstances, a decline in money growth might have a significant depressing effect on real activity. A recession is undesirable in and of itself, but also may make it impossible politically to sustain the policy.

The dilemma is that the necessary reduction of inflation expectations probably requires that money growth fall. It is irrational for anyone to bet on lower inflation on the basis of a central bank's promises with no evidence that the central bank is reducing money growth. Indeed, a recession may be necessary to provide the evidence that the central bank is serious. A constitutional amendment might avoid this problem, but at a time of great public concern about inflation could an economist make a successful case for an amendment that merely required the central bank to stabilize money growth for, say, four years before starting to reduce it?

Consider the following numbers. Using annual data and continuous compounding, M1 growth was 7.5 percent per year 1976-79 and 7.6 percent per year 1979-83. In this second period money growth was first lower, which assisted the Federal Reserve in establishing credibility, and then higher. From 1983 to $1986 \mathrm{M1}$ growth was higher yet -- an average annual rate of almost 11 percent. How much of this burst of money growth is part of a continuing velocity adjustment to lower inflation and lower interest rates and how much is the leading wave of the next acceleration of inflation?

To achieve the benefits of a constant money growth rule in the steady state there must at some point be a decision that the transition period of managed money during disinflation should be brought to an end. Just as I have come to believe that there is no satisfactory rule for managing monetary 
policy during the transition, I also believe that there is no formula to determine when the transition should terminate. Paul Volcker has earned a place in history as an extraordinarily skilled manager of the disinflation process, but his influence is unlikely to be permanent because he has not established a monetary rule or standard of some sort to guide his successors.

In summary, the last ten years has been a period rich in monetary policy lessons. The money demand function has displayed characteristics different from those that seemed so well established. Real interest rates in the 1980s were at sustained levels previously associated with depression, and yet the economy grew at a rapid rate after the 1981-82 recession. Recent experience makes clear that market interest rates are determined very importantly by expectations concerning future monetary policy. Although events have not changed the case for a monetary rule of constant money growth in the steady state, they have not been kind to the rule of gradual reductions of money growth to slow inflation. 


\section{REFERENCES}

Bordo, Michael, and Lars Jonung, "The Global Velocity Curve 1952-1982,"

National Bureau of Economic Research Working Paper No. 2074, November 1986.

Campbell, John Y., and Richard H. Clarida, "The Dollar and Real Interest : Rates," National Bureau of Economic Research Working Paper No. 2151. (forthcoming in Brunner, Karl, and Allan H. Meltzer, eds., Carnegie-Rochester Conference Series on Public Policy, Amsterdam: North Holland.)

Cooley, Thomas F., and Stephen F. LeRoy, "Identification and Estimation of Money Demand," American Economic Review, December 1981, 71, 825-44.

Deaves, Richard, Angelo Melino, and James E. Pesando, "The Response of Interest Rates to the Federal Reserve's Weekly Money Announcements: The 'Puzzle' of Anticipated Money," National Bureau of Economic Research Working Paper No. 2125, January 1987.

Fama, Eugene F., "Short-Term Interest Rates as Predictors of Inflation," American Economic Review, June 1975, 65, 269-82.

and Michael R. Gibbons, "Inflation, Real Returns and Capital Investment," Journal of Monetary Economics, May 1982, 9, 297-323.

Feldstein, Martin, and Philippe Bacchetta, "How Far Has the Dollar Fallen?," National Bureau of Economic Research Working Paper No. 2122, January 1987.

Fisher, Irving, The Purchasing Power of Money, New York: Augustus M. Kelley, 1963 (reprint of second revised edition 1922).

Friedman, Milton, and Anna J. Schwartz, A Monetary History of the United States, 1867-1960, Princeton: Princeton University Press for the National Bureau of Economic Research, 1963. 
Goldfeld, Stephen M., "The Demand for Money Revisited," in Arthur M. Okun and George L. Perry, eds., Brookings Papers on Economic Activity, 1973:3, 577638.

George L. Perry, eds., Brookings Papers on Economic Activity, 1976:3, 683-730.

Goodfriend, Marvin, "Reinterpreting Money Demand Regressions," in Brunner, Karl, and Allan H. Meltzer, eds., Understanding Monetary Regimes, CarnegieRochester Conference Series on Public Policy, 22, Amsterdam: North Holland, 1985, 207-42.

Gould, John P., and Charles R. Nelson, "The Stochastic Structure of the Velocity of Money," American Economic Review, June 1974, 64, 405-18.

Huizinga, John, and Frederic S. Mishkin, "Monetary Policy Regime Shifts and the Unusual Behavior of Real Interest Rates," in Brunner, Karl, and Allan H. Meltzer, eds., The National Bureau Method, International Capital Mobility and Other Essays, Carnegie-Rochester Conference Series on Public Policy, 24, Amsterdam: North Holland, 1986, 231-74.

Judd, John P., and John L. Scadding, "The Search for a Stable Money Demand Function: A Survey of the Post-1973 Literature," Journal of Economic Literature, 20, September 1982, 993-1023.

Laidler, David, "The Demand for Money in the United States -- Yet Again," in Brunner, Karl, and Allan H. Meltzer, eds., On the State of Macroeconomics, Carnegie-Rochester Conference Series on Public Policy, 12, Amsterdam: North Holland, 1980, 219-71.

A Comment," in Brunner, Karl, and Allan H. Meltzer, eds., Understanding Monetary Regimes, Carnegie-Rochester Conference Series on Public Policy, 22, Amsterdam: North Holland, 1985, 234-54. 
Lucas, Robert E. Jr., "Econometric Policy Evaluation: A Critique," in Brunner, Karl, and Allan H. Meltzer, eds., The Phillips Curve and Labor Markets, Carnegie-Rochester Conference Series on Public Policy, 1, Amsterdam: North Holland, 1976, 19-46.

Manikiw, N. Gregory, Jeffrey A. Miron, and David N. Weil, "The Adjustment of Expectations to a Change in Regime: A Study of the Founding of the Federal Reserve," National Bureau of Economic Research Working Paper No. 2124, January 1987.

Miller, Merton H., and Daniel Orr, "A Model of the Demand for Money by Firms," Quarterly Journal of Economics, August 1966, 80, 413-35.

Mussa, Michael, "Nominal Exchange Rate Regimes and the Behavior of Real Exchange Rates: Evidence and Implications," in Brunner, Karl, and Allan H. Meltzer, eds., Real Business $\underline{\text { Cycles, }}$ Real Exchange Rates, and $\underline{\text { Actual Policies, }}$ Carnegie-Rochester Conference Series on Public Policy, 25, Amsterdam: North Holland, 1986, 117-213.

Nelson, Charles R., and Charles I. Plosser, "Trends and Random Walks in Macroeconomic Time Series," Journal of Monetary Economics, September 1982, $10,139-62$.

Poole, William, "Whither Money Demand?" in Arthur M. Okun and George L. Perry, eds., Brookings Papers on Economic Activity, 1970:3, 485-500.

- - --_---, "Federal Reserve Operating Procedures: A Survey and Evaluation of the Historical Record since October 1979," Journal of Money, Credit and Banking, November 1982, 14, 575-96.

-_-_-_, "Is Monetarism Dead?," Business Economics, October 1986, 10-15.

Rasche, Robert H., "M1 Velocity and Money Demand Functions: Do Stable Relationships Exist?" forthcoming in Brunner, Karl and Allan H. Meltzer, eds., Carnegie-Rochester Conference Series on Public Policy, 27, Amsterdam: North Holland, 1987. 
Roley, V. Vance, "Weekly Money Supply Announcements and the Volatility of Short-Term Interest Rates," Federal Reserve Bank of Kansas City Economic Review April 1982, 3-15.

Federal Reserve Bank of Kansas City Economic Review May 1986, 27-40.

the Volatility of Short-Term Interest Rates," Federal Reserve Bank of Kansas City Economic Review February 1983, 3-15.

Schwert, G. William, "The Time Series Behavior of Real Interest Rates," in Brunner, Karl, and Allan H. Meltzer, eds., The National Bureau Method, International Capital Mobility and Other Essays, Carnegie-Rochester Conference Series on Public Policy, 24, Amsterdam: North Holland, 1986, 275-88.

Sheehan, Richard G., "Weekly Money Announcements: New Information and Its Effects," Federal Reserve Bank of St. Louis Review, August/September 1985.

Wilcox, James A., "Why Real Interest Rates Were So Low in the 1970s," American Economic Review, March 1983, 73, 44-53. 
TABLE 1

Correlation Matrix, Major Macro Variables

Quarterly, $1947.1-1986.4$

All data in logarithmic form except for time dummy

$\begin{array}{ll}\text { TIME: } & \text { Time dummy } \\ \text { GNP: } & \text { Gross National Product, Current Dollars } \\ \text { GNP82: } & \text { Gross National Product, 1982 Dollars } \\ \text { PGNP: } & \text { Gross National Product Implicit Price Deflator } \\ \text { M1: } & \text { M1 Money Stock } \\ \text { M1/P: } & \text { Ratio of M1 to PGNP } \\ \text { Aaa: } & \text { Aaa Bond Yield } \\ \text { TB: } & \text { 13-week Treasury Bill Rate, Secondary Market } \\ \text { VEL: } & \text { M1 Velocity = ratio of GNP to M1 }\end{array}$

\begin{tabular}{|c|c|c|c|c|c|c|c|c|c|}
\hline & T IME & GNP & GNP82 & PGNP & MI & $\mathrm{M} 1 / \mathrm{P}$ & Aaa & TB & VEL \\
\hline T IME & $\overline{1.000}$ & $\overline{0.993}$ & $\overline{0.993}$ & 0.967 & 0.970 & 0.400 & $\overline{0.973}$ & $\overline{0.911}$ & 0.987 \\
\hline & 0.993 & & & & & & 70 & 393 & 0.975 \\
\hline 82 & & & & & & & .964 & 0.928 & 0.991 \\
\hline & & & & & & & .949 & 0.846 & 0.939 \\
\hline & & & & & & & 0.941 & 0.837 & 0.933 \\
\hline $\mathrm{Ml} / \mathrm{P}$ & & & & & 1 & 1.000 & 0.290 & 0.233 & 0.302 \\
\hline Aaa & 73 & & & & & 290 & 1.000 & 0.932 & 0.973 \\
\hline $\mathrm{TB}$ & 11 & 0. & & & & .233 & 0.932 & 1.000 & 0.943 \\
\hline & 987 & 0.975 & 0.991 & & 0.933 & 0.302 & 0.973 & 0.943 & 1.000 \\
\hline
\end{tabular}


TABLE 2

Velocity Regressions, First Differences of Annual Data

Dependent Variable: first difference log M1 velocity

Independent Variable: first difference log Aaa bond yield

\begin{tabular}{|c|c|c|c|c|c|}
\hline Period & $\begin{array}{l}\text { Constant } \\
(\mathrm{T}-\mathrm{Sta} t)\end{array}$ & $\begin{array}{c}\text { Coefficient } \\
(\mathrm{T}-\mathrm{Stat})\end{array}$ & $\begin{array}{l}\mathrm{Adj} \\
\mathrm{R}^{2} \\
\end{array}$ & $\begin{array}{l}\text { Std. } \\
\text { Err. }\end{array}$ & $\mathrm{DW}$ \\
\hline $1916-86$ & $\begin{array}{c}0.007 \\
(1.050)\end{array}$ & $\begin{array}{c}0.238 \\
(3.005)\end{array}$ & 0.103 & 0.056 & 1.44 \\
\hline $1919-46$ & $\begin{array}{l}-0.030 \\
(-2.001)\end{array}$ & $\begin{array}{c}-0.161 \\
(-0.687)\end{array}$ & -0.020 & 0.071 & 1.81 \\
\hline $1947-81$ & $\begin{array}{c}0.032 \\
(6.723)\end{array}$ & $\begin{array}{c}0.071 \\
(1.350)\end{array}$ & 0.024 & 0.024 & 1.90 \\
\hline $1916-57$ & $\begin{array}{c}0.002 \\
(0.182)\end{array}$ & $\begin{array}{c}0.284 \\
(1.774)\end{array}$ & 0.050 & 0.070 & 1.49 \\
\hline
\end{tabular}


TABLE 3

Velocity Regressions, Levels of Annual Data

Dependent Variable: log M1 velocity

Independent Variables: RAAA $=\log$ Aaa bond yield

RPAP $=\log$ commercial paper rate

Beg $R=$ Interest rate in first year of period

End $R=$ Interest rate in last year of period

\begin{tabular}{|c|c|c|c|c|c|c|}
\hline \multirow[b]{2}{*}{ Period } & \multicolumn{3}{|c|}{ Coefficients $(T-S t a t)$} & \multirow{2}{*}{$\begin{array}{c}\mathrm{Adj} \\
\mathrm{R}^{2}\end{array}$} & \multirow{2}{*}{$\begin{array}{l}\text { Std. } \\
\text { Err. }\end{array}$} & \multirow[b]{2}{*}{ DW } \\
\hline & Constant & RAAA & RPAP & & & \\
\hline $1915-86$ & 0.227 & 0.669 & & 0.908 & 0.098 & 0.45 \\
\hline & $\begin{array}{c}0.959 \\
(29.132)\end{array}$ & & $\begin{array}{c}0.316 \\
(13.594)\end{array}$ & 0.732 & 0.168 & 0.22 \\
\hline $\begin{array}{ll}\text { Beg } & R \\
\text { End } & R\end{array}$ & & $\begin{array}{l}4.84 \% \\
9.02 \%\end{array}$ & $\begin{array}{l}4.01 \% \\
6.39 \%\end{array}$ & & & \\
\hline $1915-64$ & $\begin{array}{c}0.365 \\
(4.956)\end{array}$ & $\begin{array}{c}0.584 \\
0.796\end{array}$ & & 0.702 & 0.099 & 0.47 \\
\hline & $\begin{array}{c}0.998 \\
(45.842)\end{array}$ & $1-2.0 .02$ & $\begin{array}{c}0.188 \\
(9.556)\end{array}$ & 0.648 & 0.108 & 0.36 \\
\hline $\begin{array}{ll}\text { Beg } & R \\
\text { End } & R\end{array}$ & & $\begin{array}{l}4.84 \% \\
4.40 \%\end{array}$ & $\begin{array}{l}4.01 \% \\
3.96 \%\end{array}$ & & & \\
\hline $1920-68$ & & & & & & \\
\hline & $\begin{array}{c}0.299 \\
(4.776)\end{array}$ & $\begin{array}{c}0.645 \\
(11.103)\end{array}$ & & 0.718 & 0.108 & 0.40 \\
\hline & $\begin{array}{c}0.998 \\
(41.492)\end{array}$ & & $\begin{array}{c}0.208 \\
(9.568)\end{array}$ & 0.653 & 0.119 & 0.30 \\
\hline $\begin{array}{ll}\text { Beg } & R \\
\text { End } & R\end{array}$ & & $\begin{array}{l}6.12 \% \\
6.18 \%\end{array}$ & $\begin{array}{l}7.50 \% \\
5.90 \%\end{array}$ & & & \\
\hline $1921-86$ & $\begin{array}{c}0.271 \\
(6.435)\end{array}$ & $\begin{array}{c}0.670 \\
(26.237)\end{array}$ & & 0.914 & 0.099 & 0.420 \\
\hline & $\begin{array}{c}0.963 \\
(29.435)\end{array}$ & & $\begin{array}{c}0.326 \\
(14.278)\end{array}$ & 0.757 & 0.167 & 0.231 \\
\hline $\begin{array}{ll}\text { Beg } & R \\
\text { End } & R\end{array}$ & & $\begin{array}{l}5.97 \% \\
9.02 \%\end{array}$ & $\begin{array}{l}6.62 \% \\
6.39 \%\end{array}$ & & & \\
\hline
\end{tabular}




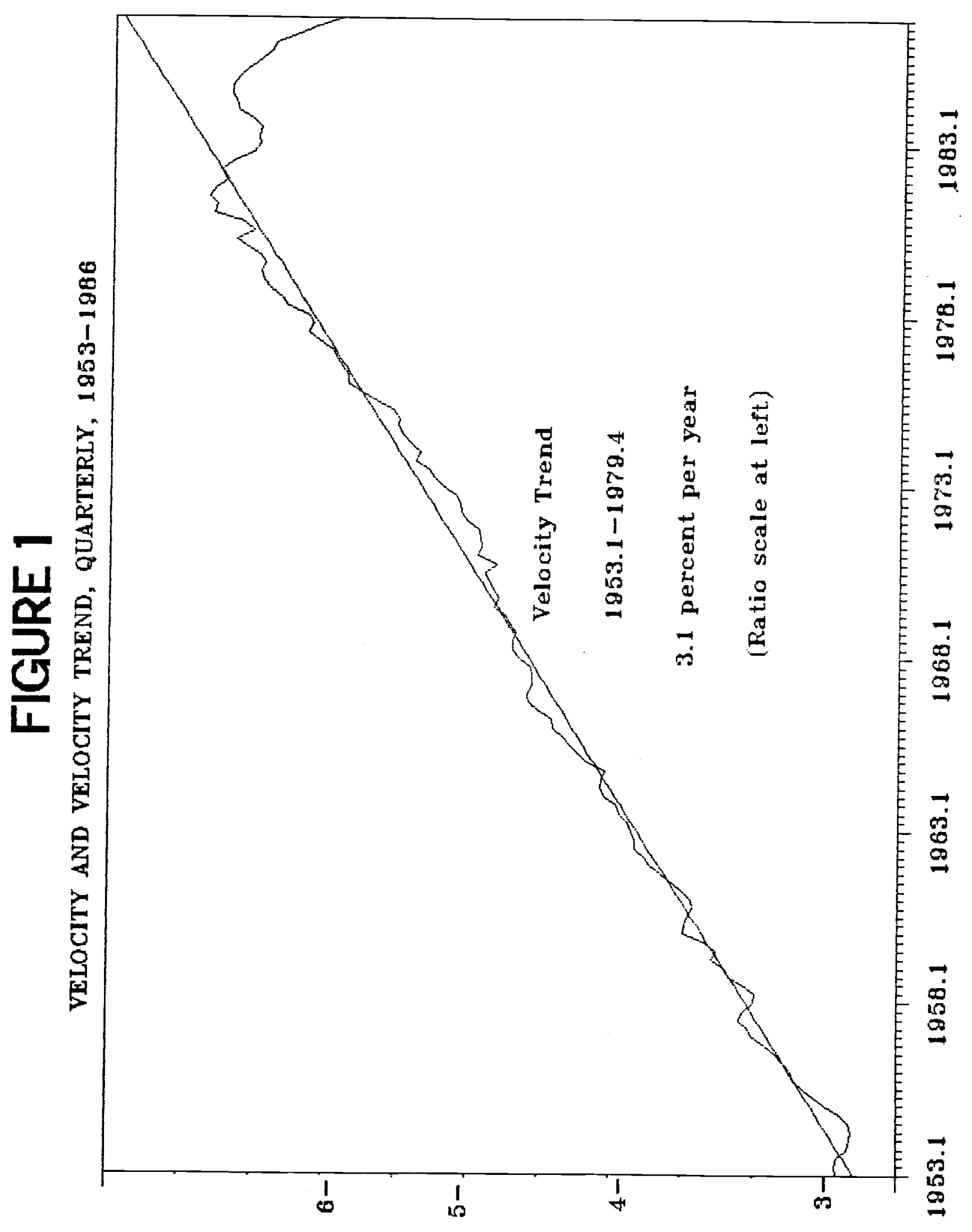




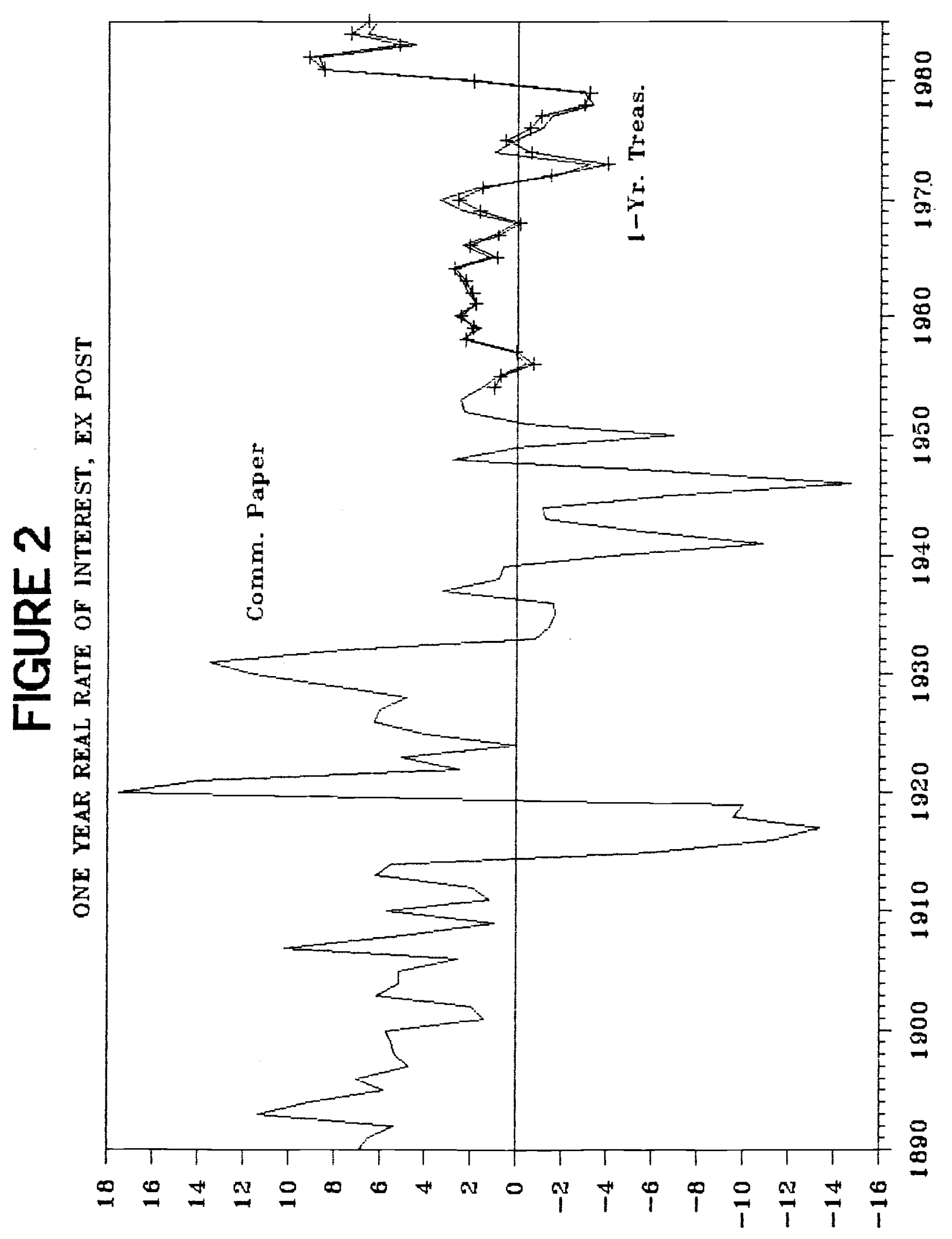




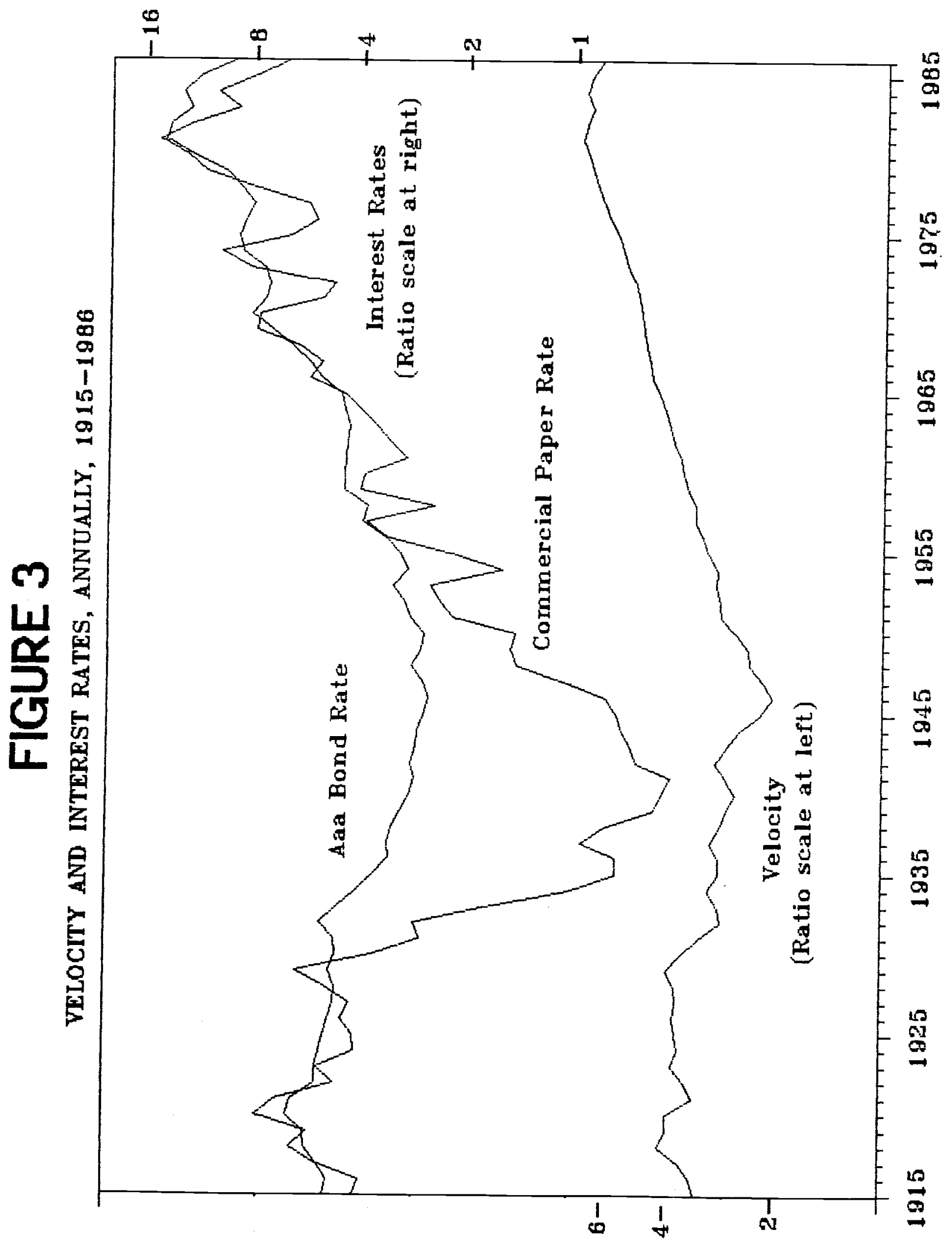


W. Poole, June, 1987

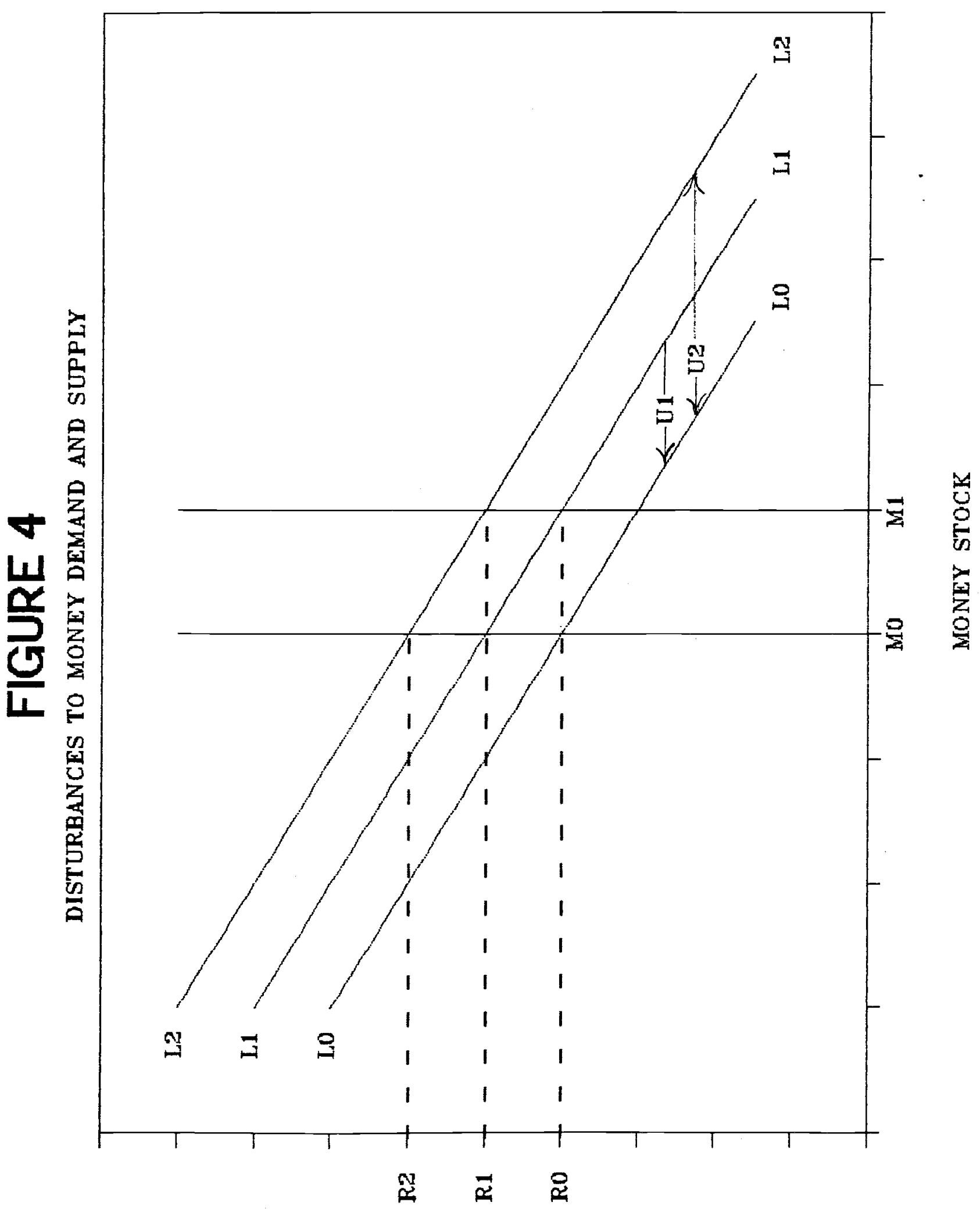




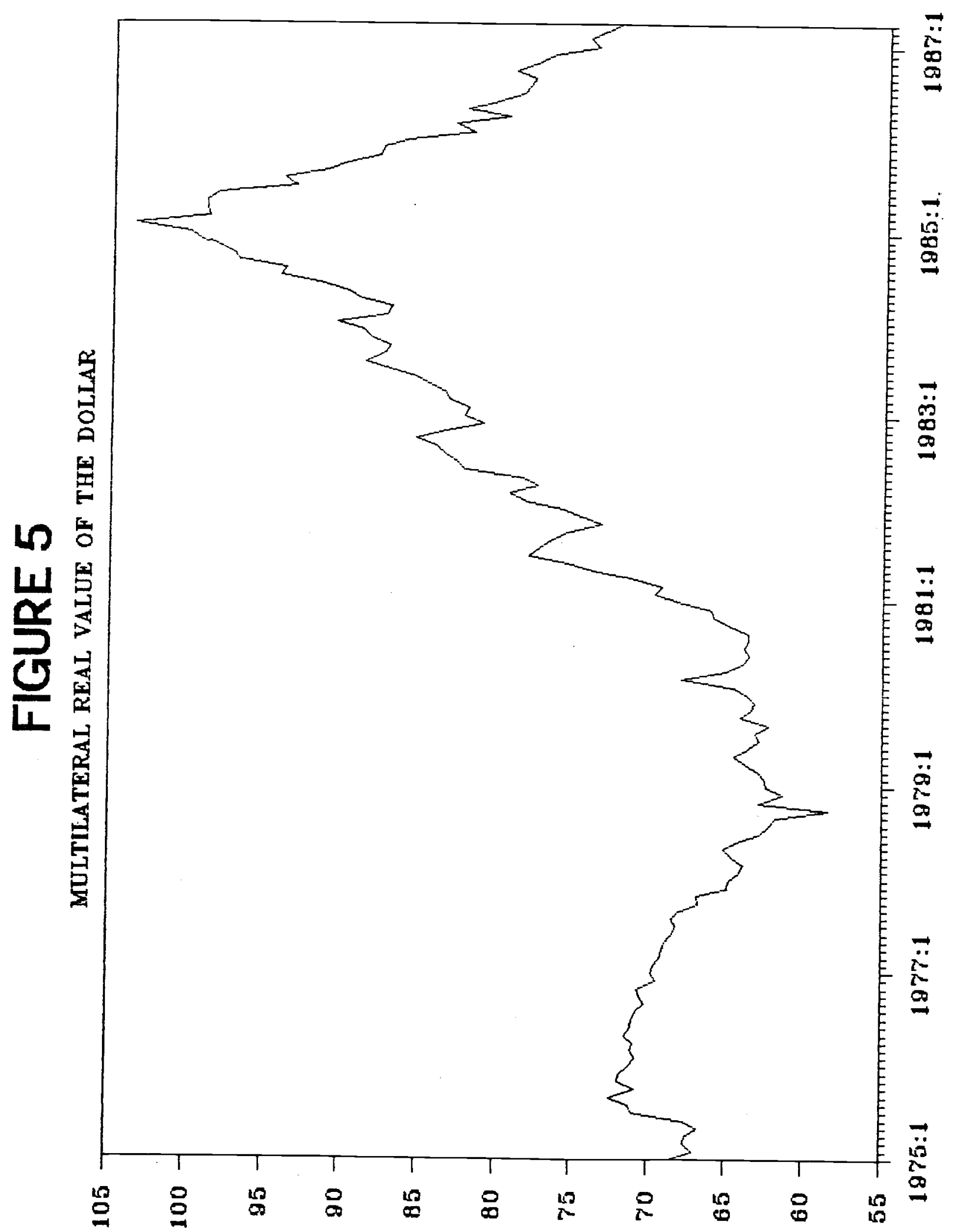




\section{APPENDIX \\ Data Sources for Figures}

Note: Data are from the Data Resources, Inc, data bank unless otherwise indicated.

Figure 1: Velocity is the ratio of current dollar GNP to M1.

GNP

1953-1986: DRI Series GNP

M1

1953-1958: Friedman-Schwartz series spliced by author to series for 1959-1986.

1959-1986: DRI Series MNY1

Figure 2: Nominal Prime Commercial Paper Rate

1890-1960: Historical Statistics of the United States, Series X-445 (4-6 mo.)

1961-1985: DRI, Series RMCML6NS (6 mo.)

Nominal Yield on Treas Securities at Constant Maturity of 1 Year 1954-1985: DRI Series RMGFCM1NS

Real yields obtained by subtracting percentage change in Consumer Price Index, All Items

1890-1912: Hist Stat Series E-135

1913-1986: DRI Series CPIU

Figure 3: Commercial Paper Rate

Same as Figure 2

Aaa Bond Rate

1915-18: Macauley Railroad bond yield, Hist Stat Series X-476, +0.22 to splice this series to the next one.

1919-46: Moody's Aaa Corp Bond Yield, Hist Stat Series X-477

1947-86: Moody's Aaa Corp Bond Yield, DRI Series RMMBCAAANS

Velocity is ratio of current dollar GNP to M1.

GNP in Current Dollars

1915-1928: Hist Stat Series F-1

1929-1986: DRI Series GNP

M1

1915-1958: Friedman-Schwartz series spliced by author to series for 1959-1986.

1959-1986: DRI Series MNY1

Figure 5: Multilaterial Real Value of the Dollar, see Feldstein-Bacchetta paper in bibliography. Data updated by Bacchetta May 1987. 


\section{ENDNOTES}

*. Professor of Economics, Brown University. Special thanks go to Kerry Reinertsen and Louis Chan for research assistance and to Data Resources, Inc. for providing data.

1. Each observation of the real rate in this figure is the annual average short-term interest rate for year $t$ less the percentage change in the annual average of the Consumer Price Index from year to year $t+1$. The figure shows the real rate calculated from the commercial paper rate for the entire period and from the one-year U.S. Treasury yield for 1954-85. Ideally, to match the inflation rate measured by annual averages of the CPI the interest rate should be the yield on a one-year security, but the only series readily available back to 1890 is the commercial paper rate. (See Appendix A for details on the data used.) The fact that there is so little daylight between the two real rate series for 1954-86 suggests that it is unlikely that the basic message of Figure 2 for $1890-1953$ is much affected by using the commercial
paper rate.

2. See the influential paper by Goldfeld (1973).

3. My argument was spelled out in Poole (1970). The same point is made much more forcefully and carefully by Cooley and LeRoy (1981). They argue that, " $[t]$ he data are such that a modestly energetic specification search will give back almost whatever interest elasticity one wishes to extract..." (p. 836). I accept this argument if the empirical analysis is confined to U.S. data for the postwar period. However, the argument surely goes too far if the data universe includes, for example, a number of hyperinflation cases or a cross section of countries with widely differing inflation rates.

4. The first quarter for which quarterly GNP data are available is 1947I. The correlation matrix for 1953.1 - 1980.4 is essentially identical to Table 1 .

5. Fisher (1963), pp. 79-88. The reference is to the 1963 reprint of the second revised edition (1922) of this book.

6. Friedman and Schwartz (1963), pp. 639-45. Friedman and Schwartz concentrated on M2 velocity whereas in this paper I am confining my attention to $M 1$ velocity. Although these two velocities have different levels and different secular trends, changes in their growth rates from one subperiod to another are quite similar.

7. More precisely, the short rate measures the true opportunity cost with greater error than does the long rate. Goodfriend (1985) provides an analytical argument that estimated lagged adjustment terms in the standard money demand function are a spurious result of measurement error and that measurement error leads to biased estimates of elasticities. He does not, however, provide elasticity estimates corrected for the problems he notes.

8. The standard deviations of the log levels of the commercial paper rate and AAA bond rate for $1915-86$ are 0.46 and 0.88 , respectively. 
9. This paragraph should not be read as claiming that real assets are irrelevant to money demand. There is ample evidence that agents flee from both money and fixed income assets into goods during periods of hyperinflation. During moderate inflations, as in the United States in the 1970 s, agents may economize on money by holding inventories of goods or accelerating purchases of consumer durables.

10. Laidler (1985) provides a short discussion of the buffer stock argument and a bibliography of relevant papers.

11. I explored these ideas in a formal but incomplete fashion in Poole (1982).

12. Bordo and Jonung (1986) provide cross section evidence for the hypothesis that the income elasticity of demand for real money balances is above unity for relatively low per capita income countries and below unity for relatively high per capita income countries. However, these authors do not report numerical estimates of income elasticities.

13. See Fama and Gibbons (1982) and the references in their paper.

14. For real rate estimates and charts see Huizinga and Mishkin (1986) and the discussion of the Huizinga-Mishkin paper by Schwert (1986).

15. For a summary of these positions see Campbell and Clarida (1987), 30-37. This paper also contains a bibliography of many of the contributions to this debate.

16. See Wilcox (1983) for an analysis of the effects of supply shocks on the real rate of interest and a bibliography of relevant papers on supply shocks.

17. For evidence on the behavior of the real exchange rate under fixed and floating rate regimes see Mussa (1986) and papers referenced by Mussa.

18. Sheehan (1985) provides a survey of findings and a bibliography. See also the paper by Deaves, Melino, and Pesando (1987).

19. See Roley (1982) p.9 and Roley (1983) p.10.

20. Another interesting piece of evidence on the market's response to monetary policy is in a recent paper by Manikiw, Miron, and Weil (1987). These authors examined the effect of the opening of the Federal Reserve System in November 1914 on the time series characteristics of interest rates and the term structure of rates. They conclude that the market responded quickly and in the direction expected from a priori knowledge about how the Fed would operate.

21. From market commentary and the behavior of nominal interest rates, it appears that inflation expectations did not begin to rise again until early 1987.

22. See Poole (1986) for a more complete account. 
23. Using annual average data for the Consumer Price Index, the inflation rate was -1.3 percent in 1928 and -10.3 percent in 1932 , or a deceleration of 9.0 percentage points. In 1980 the inflation rate was 13.5 percent and in 1985 the rate was 3.6 percent, or a deceleration of 9.9 percentage points. Under the gradualism scenario the deceleration of inflation would have been greater. Different price indexes would yield somewhat different numbers but would not alter the conclusion. 